\title{
Antisense Oligonucleotide-Mediated Exon Skipping for Duchenne Muscular Dystrophy: Progress and Challenges
}

\author{
Virginia Arechavala-Gomeza, Karen Anthony, Jennifer Morgan, Francesco Muntoni
}

Dubowitz Neuromuscular Centre, UCL Institute of Child Health, 30 Guilford Street, London, WC1N 1EH, UK

\begin{abstract}
Duchenne muscular dystrophy (DMD) is the most common childhood neuromuscular disorder. It is caused by mutations in the $D M D$ gene that disrupt the open reading frame (ORF) preventing the production of functional dystrophin protein. The loss of dystrophin ultimately leads to the degeneration of muscle fibres, progressive weakness and premature death. Antisense oligonucleotides (AOs) targeted to splicing elements within DMD pre-mRNA can induce the skipping of targeted exons, restoring the ORF and the consequent production of a shorter but functional dystrophin protein. This approach may lead to an effective disease modifying treatment for DMD and progress towards clinical application has been rapid. Less than a decade has passed between the first studies published in 1998 describing the use of AOs to modify the DMD gene in mice and the results of the first intramuscular proof of concept clinical trials. Whilst phase II and III trials are now underway, the heterogeneity of DMD mutations, efficient systemic delivery and targeting of AOs to cardiac muscle remain significant challenges. Here we review the current status of AO-mediated therapy for $\mathrm{DMD}$, discussing the pre-clinical, clinical and regulatory hurdles and their possible solutions to expedite the translation of AO-mediated exon skipping therapy to clinic.
\end{abstract}

Keywords: Antisense oligonucleotides, clinical trials, duchenne muscular dystrophy, becker muscular dystrophy, dystrophin, exon skipping, RNA therapy

\section{Introduction}

\section{Duchenne muscular dystrophy}

Duchenne muscular dystrophy (DMD) is a fatal, X-linked, neuromuscular disorder that affects 1 in 3,500 newborn boys. Patients are typically diagnosed as toddlers; they develop progressive muscle weakness and cardiomyopathy and lose the ability to walk by their early teens. Unless appropriate standards of care (including non-invasive ventilation, glucocorticoid and cardio-protective treatment) are implemented, premature death by cardiac or respiratory failure occurs in the second decade of life (1-3).

DMD is caused by mutations in the $D M D$ gene that disrupt the open reading frame (ORF) thus aborting the full translation of its protein product, dystrophin $(4,5)$. The $D M D$ gene comprises 79 exons and the majority ( $65 \%$ ) of mutations responsible for DMD are out-of-frame deletions, 
although duplications ( 10\%), small mutations including non-sense and splice site changes ( $22 \%)$ and deep intronic mutations ( $3 \%)$ are also documented (6, 7). Some $D M D$ deletions are more frequent than others and the gene has two deletion hotspots (6): the most commonly mutated region is exons $45-55$ followed by exons 2-19.

Dystrophin is located underneath the sarcolemma and connects the subsarcolemmal cytoskeleton to the extracellular matrix by binding $\mathrm{N}$ terminally to cytoskeletal F-actin and to $\beta$-dystroglycan via a cysteine rich domain near the C-terminus (8) (Top panel, Figure 1). It contains four main functional units: an $\mathrm{N}$-terminus, a central rod domain, a cysteine rich domain and a C-terminal domain. The central rod domain consists of 24 spectrin-like repeats and four hinge domains (9). Dystrophin interacts with actin at both its $\mathrm{N}$-terminus and via spectrin-like repeats 11-17; the Cterminus has also recently been shown to allosterically affect actin binding (10). The cysteine rich domain binds to $\beta$ dystroglycan (BDG) (11-15) and the Cterminal domain is required for binding to syntrophin (16) and dystrobrevin (17). These and other sarcolemmal proteins such as the sarcoglycans are components of the dystrophin associated glycoprotein complex (DGC). Dystrophin and the DGC play an important role in stabilising the muscle fibre against the mechanical forces of muscle contraction by providing a shock-absorbing connection between the cytoskeleton and the extracellular matrix.
Loss of dystrophin leads to disruption of the complex, which results in inflammation, increased intracellular calcium influx, muscle degeneration and replacement of muscle with adipo-fibrous tissue (4). In addition, dystrophin plays a role in signalling and is associated with members of the stretch-activated calcium channels; their mislocalisation and dysfunction in dystrophic muscle contributes to disease progression (18). Spectrin repeats 16 and 17 within the central rod domain, encoded by exons 4245 , are also required for binding to neuronal nitric oxide synthase (nNOS) (11, $12,19)$. nNOS regulates the blood flow in skeletal muscle (20); disruption of this pathway may contribute to DMD pathogenesis by inducing paradoxical vasoconstriction during exercise (21).

Naturally-occurring dystrophin positive "revertant fibres" (isolated or less commonly small clusters of fibres strongly positive for dystrophin) and "traces" (fibres expressing very low levels of dystrophin at the sarcolemma) occur in more than $50 \%$ of the muscle biopsies of DMD patients (22). Revertant fibres represent a very small percentage of the total fibres, in which somatic mutations or stochastic alternative splicing events of the dystrophin pre-mRNA lead to exon skipping, the restoration of the ORF and consequent expression of dystrophin (23, 24). Revertant dystrophins are correctly localised to the sarcolemma and associate with other DGC proteins, suggesting a retained function $(25,26)$. Revertant fibres have been well characterised in the 
Please cite as Arechavala-Gomeza et al, Current Gene Therapy 2012

mouse model of DMD, the $m d x$ mouse $(24,27,28)$. Whilst traces have not been described in the $m d x$ mouse, they are present in approximately a third of DMD patients (22) and may represent up to $25 \%$ of the total muscle fibres (29). The molecular mechanism of trace dystrophin expression remains to be elucidated, but it is thought to be at least in part different from that of revertant fibres. For example, traces can express different dystrophin epitopes than the surrounding revertant fibres (22).

\section{Becker muscular dystrophy}

Mutations in the $D M D$ gene are also responsible for a milder disorder, Becker muscular dystrophy (BMD), a disease with an extremely variable spectrum of severity ranging from patients with walking difficulties in their late teens or early twenties, to the majority of individuals in whom ambulation is preserved into late adulthood and who have an essentially normal lifespan (30). DMD and BMD mutations differentially affect the DMD gene: in DMD the mutations disrupt the reading frame, while mutations that cause BMD maintain the $\operatorname{ORF}(31,32)$ leading to the production of an internally deleted dystrophin protein. The size of the deletion does not correlate with the severity of the disease, as long as the reading frame rule is maintained (33-40), and provided crucial domains of dystrophin such as the $\beta$ dystroglycan binding site are not removed by the deletion. While the central and distal rod domain is less vital for function
(35), (some patients missing these domains only have very mild disease manifestations such as myalgia and muscle cramps, and mild weakness), in frame deletions that affect the binding of dystrophin to other proteins such as cytoskeletal actin or $\beta$-dystroglycan result in a severe phenotype $(41,42)$.

The existence of revertant fibres in DMD and the occurrence of mildly affected BMD individuals with in-frame deletions suggest that it is feasible to modify splicing by exon skipping (Figure 1 ) and induce the production of functional dystrophin in DMD patients, as long as crucial domains of dystrophin are not disrupted. Artificially restoring the ORF in this way is thus an attractive therapeutic strategy for DMD, as approximately $70 \%$ of DMD patients have mutations amenable to exon skipping (43).

Figure1 Exon skipping principle. (Next page) Upper panel: Schematic representation of dystrophin mRNA (in-frame exons are represented as square boxes, out-of-frame exons round or arrow boxes). Normal splicing of these exons produces dystrophin protein (pictured immediately below) retaining functional protein-binding domains and correctly localised to the sarcolemma (see section of control muscle stained with anti-dystrophin antibody Dys2). Lower panel: representation of dystrophin pre-mRNA highlighting the differences in splicing between a Del48-50 DMD patient (left) and a Del48-51BMD patient (right). The DMD deletion disrupts the open reading frame (ORFs) which results in unstable mRNA and the absence of functional dystrophin protein in muscle sections. In the BMD patient the deletion maintains the ORF and generates the production of an internally deleted dystrophin isoform that retains the critical amino and carboxyl terminals and Cysteine rich domains. The ORF can be corrected by forced skipping of exon 51 by directing antisense oligonucleotides to sequences within exon 51 or to neighbouring intronic regions. Exon 51 skipping restores the ORF, generating a dystrophin equivalent to that of the BMD patient. Insert table: Theoretical applicability of single exon skipping in a series of DMD deletions. 


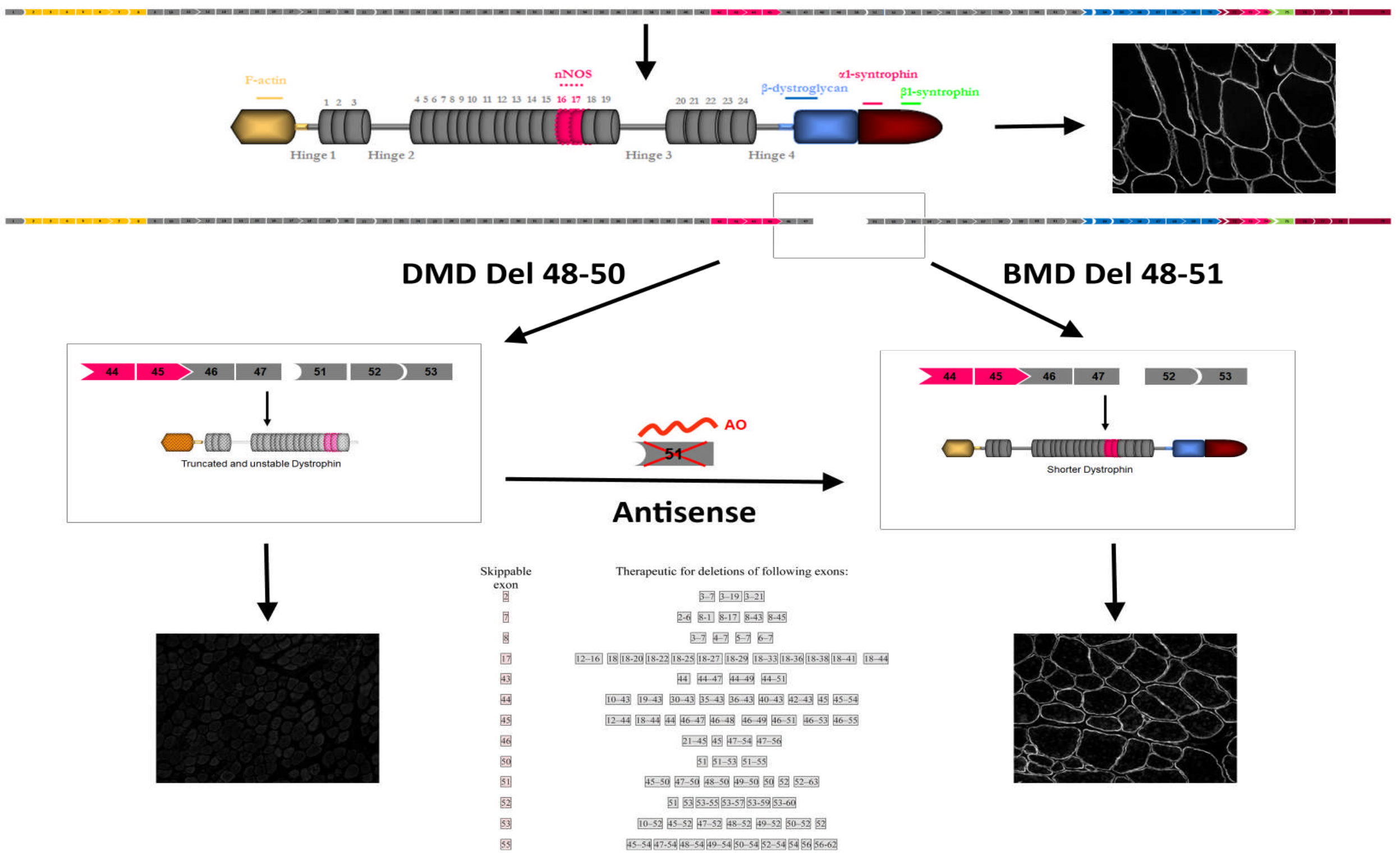


Author's Pre-print copy

Please cite as Arechavala-Gomeza et al. Current Gene Therapv 2012

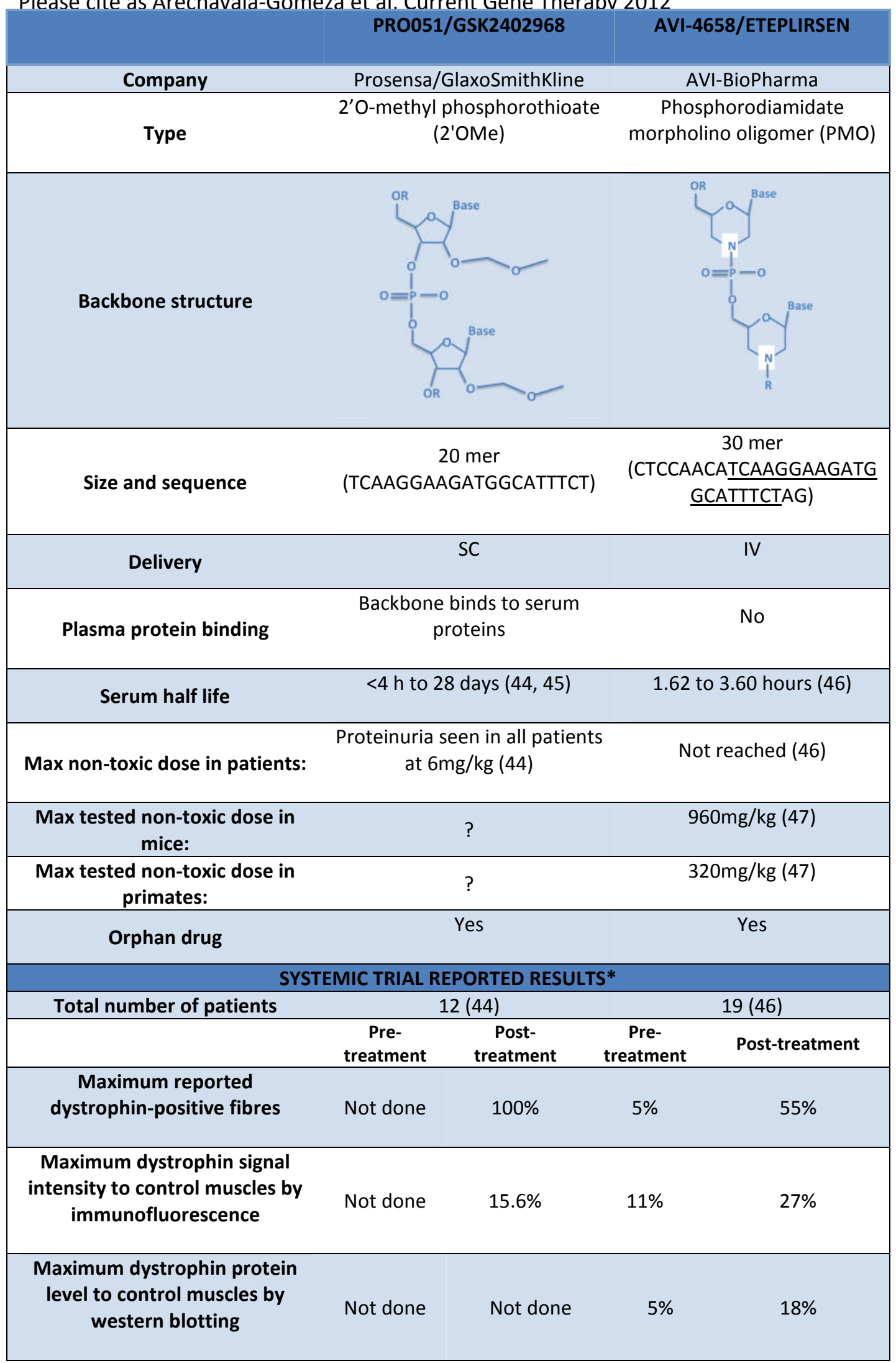

Table 1 Comparison between the two leading candidates for exon 51 skipping.SC = subcutaneous; IV = intravenous; IM = intramuscular 
Antisense oligonucleotide-mediated exon skipping

Antisense oligonucleotides (AOs) targeted to splicing elements represent the most clinically advanced therapeutic tools developed to induce dystrophin exon skipping $(48,49)$. AOs are typically $20-30$ nucleotides in length, and complementary in sequence to regions of the pre-mRNA transcript (50). While several AO chemistries exist, the two AOs in clinical development for DMD are 2'O-methyl phoshophorothioate oligoribonucleotide (2'OMe) and phosphorodiamidate morpholino oligomers (PMO), (Table 1) and $(51,52)$ for a detailed review. 2'OMe AOs bind to albumin, showing high plasma concentrations and long half-lives (45); this might be an advantage as PK studies indicate a longer persistence in blood compared to PMO (up to 28 days as opposed to less than 4 hours); however binding to protein has been shown to trigger activation of the immune system, anaphylaxis, hypotension, or antiarrhythmic effects in preclinical and clinical studies (53). PMOs are not metabolised and are resistant to endonucleases (54); they are rapidly eliminated from the bloodstream as they are uncharged and do not bind serum proteins, which is likely why they have not been associated with the side effects mentioned for the 20Me clinical studies. Both AOs have proven successful in preclinical mouse models (55-58) and as far as the PMO is concerned, also the more severe dog model (59), in which systemic delivery has resulted in dystrophin protein production $(60,61)$ and physiological improvement (58) of skeletal muscle.

\section{Clinical progress}

Both PMO (AVI-4658/eteplirsen) and 2'OMe (GSK-2402968) AOs targeting exon 51 (which will restore the ORF in the largest group of DMD patients (13\%)) have proven successful at inducing local dystrophin expression in pivotal proof-ofconcept intramuscular clinical trials (62, 63). Recently, systemic studies using the two different $A O$ chemistries have been completed (Table 2) (44, 46), demonstrating that $A O$ therapy for $D M D$ is indeed safe and well tolerated with no significant drug-related adverse events. Both studies reported significant dystrophin restoration in a dosedependent manner as determined by western blotting and immunohistochemistry, with levels of dystrophin approaching $20 \%$ of normal levels in the PMO study.

The outcome of randomised placebocontrolled studies of both eteplirsen and GSK-2402968 is expected in 2012 and further studies are planned. Table 2 summarises the design of both completed and ongoing ClinicalTrials.gov registered studies correct at the time of publication. In addition, AOs for exons 45, 52, 53 and 55 are undergoing pre-clinical development by GSK whilst AVI BioPharma is developing PMOs targeting exons 45, 50 and 53. Plans to extend trials of systemically-delivered AOs to nonambulant boys are also underway for exon 51 skippable patients (both with eteplirsen and GSK2402968). 


\begin{tabular}{|c|c|c|c|c|c|c|c|c|c|c|c|}
\hline \multirow[b]{3}{*}{ Study drug } & \multicolumn{4}{|c|}{ Completed } & \multicolumn{7}{|c|}{ Ongoing } \\
\hline & \multicolumn{2}{|c|}{ Intra-muscular } & \multicolumn{2}{|c|}{ Systemic } & \multicolumn{7}{|l|}{ Systemic } \\
\hline & $\begin{array}{l}\text { AVI-4658 } \\
\text { (Eteplirsen) }\end{array}$ & $\begin{array}{l}\text { PRO051 (GSK- } \\
\text { 2402968) }\end{array}$ & $\begin{array}{l}\text { AVI-4658 } \\
\text { (Eteplirsen) }\end{array}$ & $\begin{array}{l}\text { PRO051 (GSK- } \\
\text { 2402968) }\end{array}$ & $\begin{array}{l}\text { AVI-4658 } \\
\text { (Eteplirsen) }\end{array}$ & $\begin{array}{l}\text { PRO051 (GSK- } \\
\text { 2402968) }\end{array}$ & $\begin{array}{l}\text { PRO051 (GSK- } \\
\text { 2402968) }\end{array}$ & $\begin{array}{l}\text { PRO051 (GSK- } \\
\text { 2402968) }\end{array}$ & $\begin{array}{l}\text { PRO051 (GSK- } \\
\text { 2402968) }\end{array}$ & $\begin{array}{l}\text { PRO051 (GSK- } \\
\text { 2402968) }\end{array}$ & PRO044 \\
\hline $\begin{array}{l}\text { ClinicalTrials.gov } \\
\text { identifier }\end{array}$ & NCT00159250 & $\begin{array}{l}\text { Netherlands } \\
\text { trial register: } \\
\text { NTR712 }\end{array}$ & NCT00844597 & $\begin{array}{l}\text { EudraCT } \\
\text { number: 2007- } \\
\text { 004819-54 }\end{array}$ & NCT01396239 & NCT01153932 & NCT01462292 & NCT01254019 & NCT01128855 & $\begin{array}{l}\text { NCT01451281 } \\
\text { (parent study: } \\
\text { NCT01462292) }\end{array}$ & NCT01037309 \\
\hline Phase & $1 / I I$ & $1 / 11$ & $1 / I I$ & $1 / 11$ & II & II & II & IIII & 1 & $n / a$ & $1 / I I$ \\
\hline Study design & $\begin{array}{l}\text { Single-blind, } \\
\text { placebo- } \\
\text { controlled, dose- } \\
\text { escalation }\end{array}$ & Single dose & $\begin{array}{l}\text { open-label, } \\
\text { dose-escalation }\end{array}$ & $\begin{array}{l}\text { open-label, } \\
\text { dose-escalation }\end{array}$ & $\begin{array}{l}\text { Randomised, } \\
\text { double-blind, } \\
\text { placebo- } \\
\text { controlled, } \\
\text { multiple Dose }\end{array}$ & $\begin{array}{l}\text { Randomised, } \\
\text { double blind, } \\
\text { placebo } \\
\text { controlled }\end{array}$ & $\begin{array}{l}\text { Randomised, } \\
\text { double blind }\end{array}$ & $\begin{array}{l}\text { Randomised, } \\
\text { double blind }\end{array}$ & $\begin{array}{l}\text { Double-blind, } \\
\text { escalating dose, } \\
\text { randomized, } \\
\text { placebo-controlled }\end{array}$ & $\mathrm{n} / \mathrm{a}$ & $\begin{array}{l}\text { Non-randomised, } \\
\text { open label }\end{array}$ \\
\hline Chemistry & PMO & 2'OMe & PMO & 2'OMe & PMO & 2'OMe & 2'OMe & 2'OMe & 2'OMe & 2'OMe & $2^{\prime} \mathrm{OMe}$ \\
\hline Number of patients & 7 & 4 & 19 & 12 & 12 & 54 & 54 & 180 & 32 & 85 & 18 \\
\hline Target exon & 51 & 51 & 51 & 51 & 51 & 51 & 51 & 51 & 51 & 51 & 44 \\
\hline $\begin{array}{l}\text { Ambulant/Non } \\
\text { Ambulant }\end{array}$ & Ambulant & Ambulant & Ambulant & Ambulant & Ambulant & Ambulant & Ambulant & Ambulant & Non-ambulant & Ambulant & Ambulant \\
\hline Delivery & IM (EDB) & $\mathrm{IM}(\mathrm{TA})$ & IV & Subcutaneous & IV & Sub-cutaneous & Sub-cutaneous & Sub-cutaneous & Subcutaneous & Sub-cutaneous & $\begin{array}{l}\text { Subcutaneous \& } \\
\text { I.V }(1.5,5 \mathrm{mg} / \mathrm{kg})\end{array}$ \\
\hline Dose & 0.09 and $0.9 \mathrm{mg}$ & $0.8 \mathrm{mg}$ & $\begin{array}{l}0.5,1,2,4,10, \\
\text { and } 20 \mathrm{mg} / \mathrm{kg} \\
\text { body weight }\end{array}$ & $\begin{array}{l}0.5,2,4 \text { and } 6 \\
\mathrm{mg} / \mathrm{kg} \text { body } \\
\text { weight }\end{array}$ & $\begin{array}{l}30,50 \mathrm{mg} / \mathrm{kg} \\
\text { body weight }\end{array}$ & $\begin{array}{l}6 \mathrm{mg} / \mathrm{kg} \text { body } \\
\text { weight }\end{array}$ & $\begin{array}{l}3,6 \mathrm{mg} / \mathrm{kg} \text { body } \\
\text { weight }\end{array}$ & $\begin{array}{l}6 \mathrm{mg} / \mathrm{kg} \text { body } \\
\text { weight }\end{array}$ & $\begin{array}{l}3,6,9 \& 12 \mathrm{mg} / \mathrm{kg} \\
\text { body weight }\end{array}$ & $\begin{array}{l}3,6 \mathrm{mg} / \mathrm{kg} \text { body } \\
\text { weight }\end{array}$ & $\begin{array}{l}0.5,1.5,5,8,10 \\
12 \mathrm{mg} / \mathrm{kg} \text { body } \\
\text { weight }\end{array}$ \\
\hline $\begin{array}{l}\text { Frequency of } \\
\text { administration }\end{array}$ & Single & Single & Weekly & Weekly & Weekly & $\begin{array}{l}\text { Weekly \& twice } \\
\text { weekly }\end{array}$ & Weekly & Weekly & Single & Weekly & Weekly \\
\hline Duration & 3-4 weeks & 4 weeks & 12 weeks & 12 weeks & 24 weeks & 24-48 weeks & 24 weeks & 1 year & 5 weeks & 24 weeks & 5 weeks \\
\hline $\begin{array}{l}\text { Primary outcome } \\
\text { measure }\end{array}$ & Safety & Adverse events & Safety & Safety & $\begin{array}{l}\text { Dystrophin } \\
\text { positive fibers }\end{array}$ & Efficacy & $\begin{array}{l}6 \text { minute walk } \\
\text { distance test }\end{array}$ & Efficacy & Pharmacokinetics & $\begin{array}{l}\text { MRI changes in } \\
\text { skeletal muscle }\end{array}$ & $\begin{array}{l}\text { Safety, } \\
\text { tolerability, } \\
\text { pharmacokinetics } \\
\text { \& dystrophin } \\
\text { expression }\end{array}$ \\
\hline Start Date & October 2007 & 2006 & January 2009 & 2008 & July 2011 & $\begin{array}{l}\text { September } \\
2010\end{array}$ & October 2011 & December 2010 & July 2010 & $\begin{array}{l}\text { September } \\
2011\end{array}$ & December 2009 \\
\hline Completion date & March 2009 & 2007 & December 2010 & 2011 & $\begin{array}{l}\text { June } 2012 \\
\text { (estimated) }\end{array}$ & $\begin{array}{l}\text { September } \\
2012 \\
\text { (estimated) }\end{array}$ & $\begin{array}{l}\text { April } 2013 \\
\text { (estimated) }\end{array}$ & $\begin{array}{l}\text { December } 2012 \\
\text { (estimated) }\end{array}$ & November 2011 & $\begin{array}{l}2012 \\
\text { (estimated) }\end{array}$ & $\begin{array}{l}\text { December } 2012 \\
\text { (estimated) }\end{array}$ \\
\hline
\end{tabular}


Author's Pre-print copy

Please cite as Arechavala-Gomeza et al, Current Gene Therapy 2012

(Previous page) Table 2 Summary of completed and on-going exon skipping clinical trials for DMD $I V=$ intravenous; $I \mathrm{M}=$ intramuscular

\section{Current challenges}

In-vitro optimisation of novel AOs

Systematic screening for AO targets has already identified targets for most of the 79 dystrophin exons (64-66), but there is variability in the processes used to design and evaluate target AOs. For example, variations in the cell type for in vitro studies, transfection reagents, time of evaluation and quantification of skipped product $(64,67-69)$ make inter-study comparisons difficult. Despite the fact that bioinformatic tools (70-73) can provide optimal target areas for $A O$ binding, and help rank $A O$ sequences according to their predicted bioactivity $(43,65)$, empirical analysis in-vitro is always necessary to confirm the suitability of the sequence (69). Importantly, restoration of dystrophin expression can only be shown in differentiated myotubes derived from patients' cells as dystrophin is only expressed in myotubes and not in myoblasts. Ideally, cells from several patients holding different amenable deletions should be used to test the efficacy of an $\mathrm{AO}$, as the intronic breakpoints differ between patients and might affect splicing efficiency (74). Primary myoblasts derived from DMD muscle biopsies can be difficult to expand in culture $(75,76)$ and the extent of myogenic differentiation of DMD myoblasts is often low $(77,78)$. Similar levels of differentiation would be required for quantitative comparison of the efficacy of the same $A O$ on cells from patients with different mutations. In order to improve the proliferative capacity of human myoblasts so that large numbers of cells are available for replicate experiments, techniques to immortalise human myoblasts have been developed (79).

A less invasive alternative to the use of muscle biopsies to prepare satellite cellderived myoblasts, are fibroblasts prepared from a skin biopsy. Fibroblasts can be induced to differentiate into myotubes by forced expression of the myogenic regulatory factor MyoD (80). However, the levels of $D M D$ transcripts in myotubes derived from fibroblasts can be low and the variable extent of myogenic differentiation should be controlled for in comparative experiments.Transgenic mice, harboring the entire human DMD locus, may be used to test antisense oligonucleotides (64, 67, 81-83). However, these mice also carry the mouse dystrophin gene and have no skeletal muscle pathology.

\section{Outcome measures}

A validated set of clinical outcome measures for ambulant DMD patients is in use in the ongoing phase II and III clinical trials. Future trials on non-ambulant patients pose a further challenge where robust measurements of upper limb strength and function in late disease stage are required. While clinical outcome measures are needed to demonstrate 
Please cite as Arechavala-Gomeza et al, Current Gene Therapy 2012

functional improvement, biochemical outcome measures (BOMs) are required to monitor AO efficacy. However, critical differences in the methodology used between the different research centres are of concern. Standardised BOMs are essential in order to reliably compare the efficacy of the different chemistries and dosing regimens. Specifically, the most reliable methods for quantification of both exon skipping and dystrophin restoration must now be established through initiatives such as the TREATNMD registry of outcome measures for neuromuscular disorders (www.researchrom.com/) and from ongoing international collaborative studies aiming to cross-validate standard operating procedures. The outcomes of these should be the standardisation of methodology across centres that could be presented to regulatory authorities as the preferred BOMs in future clinical trials.

The efficacy of exon skipping is measured at both the RNA and protein level. Nested RT-PCR is traditionally used to assess and quantify (semi-quantitatively) AO efficacy at the RNA level $(84,85)$. To detect transcripts using this method, it is necessary to use up to 70 PCR cycles after which linearity is lost and it is therefore not possible to accurately quantify the percentage of exon skipping. Thus several quantitative methods are currently in development such as qRT-PCR using highly specific TaqMan assays for skipped and total dystrophin targets. The advent of digital PCR and micro fluidic technology enables the high throughput analysis of patient RNA. For example, exon skipping could be assessed by measuring changes in mRNA decay pre and post treatment using TaqMan assays that cover all 79 dystrophin exons. Such a platform, the FluiDMD, has recently been described which simultaneously analyses 85 TaqMan assays recognising 76 out of 78 DMD exon junctions (86).

As the aim of AO-mediated exon skipping is to restore dystrophin production, reliable methods to quantify dystrophin expression are vital. The presence of dystrophin traces and revertant fibres in DMD muscles (22) makes it essential to compare treated muscles with a pretreatment biopsy of the same patient, in order to accurately distinguish and quantify AO-mediated dystrophin protein production (87). The two most commonly used methods are western blotting and immunostaining (46, 87, 88). Consideration should be given to the antibodies to be used, which must be sensitive, specific and have an epitope appropriate for the dystrophin exons retained following exon skipping.

As muscle biopsies are invasive and sample a single muscle, there are limitations in their use to monitor response to therapy and efforts are being made to identify non-invasive biomarkers to monitor DMD disease progression. Studies aimed at validating the role of magnetic resonance imaging (89) and spectroscopy as well as serum or urine biomarkers such as small non coding RNAs (such as miRNA) are currently underway both in animal models and in clinical 
Author's Pre-print copy

Please cite as Arechavala-Gomeza et al, Current Gene Therapy 2012

studies; it is hoped that these will reduce the need for muscle biopsies (90).

\section{Functionality of the de novo dystrophin protein}

Whilst the primary outcome measure of the completed systemic trials was clinical safety, the GSK-2402968 study also reported a modest improvement in the 6 minute walk test which is encouraging (44). From a biochemical perspective, data from both the intramuscular and systemic eteplirsen trials further indicate that the internally deleted dystrophins generated by exon skipping in different patients are indeed functional, as they led to the restoration of proteins of the DGC (46, 91). Additional evidence of functional improvement is provided by a reduction in cytotoxic $T$ cells within treated muscle biopsies (46); this is promising considering that the pre-symptomatic induction of inflammatory cascades and the invasion of muscle by immune cells is one of the earliest pathways induced in dystrophin deficient muscle and is thought contribute to DMD pathology $(92,93)$. However, the possibility of an immunological reaction both against revertant and novel dystrophin epitopes remains a possibility (94) and presents a new issue to address in future clinical trials that will require the assessment of any pre-existing immunological response to dystrophin epitopes in patients prior to their inclusion in a clinical trial, as well as any post-treatment response to the newlygenerated dystrophin protein (94).
Some mild or asymptomatic BMD patients naturally express the dystrophin proteins that we aim to produce by exon skipping (32). A recent study correlated dystrophin and dystrophin-associated protein expression with disease severity in a cohort of BMD patients (26). The amount of dystrophin, nNOS and BDG correlated to clinical severity and BMD patients with deletions equivalent to those created by exon 51 skipping have higher dystrophin levels than either those with large multiexon deletions, or those harbouring exon 53 skippable deletions (26). These findings demonstrate the therapeutic potential of the protein that will be generated by exon 51 skipping trials whilst the functionality of other dystrophins, especially those with larger internal deletions, is less clear (43, 95-97).

\section{Variability of response}

The completed AO-mediated exon skipping clinical trials have revealed a high degree of variability in patient response, even between patients harbouring the same deletions (46). These findings suggest that the variability is unlikely to be due to inter-patient differences in stability of the resultant protein, immunological response, or the pharmacodynamics of the PMO (46). However, it has been suggested (46) that differences in the genetic background, such as intronic deletion breakpoints, differences in the efficiencies of mRNA splicing, or differences in the vascular access of the $A O$ to individual muscles may contribute to the variable response. 
An important future goal must be to understand the mechanisms behind this variability and why some patients respond better to treatment than others. Interestingly studies in the $m d x$ mouse with both PMO and 2'OMe and in the GRMD dog using PMO have identified similar variability in response, even in the same animal, when different muscles were studied $(61,98-100)$. This- indirectlypoints towards stochastic events involved in delivering the $\mathrm{AO}$ to skeletal muscle rather than a genetic difference, although more studies are needed to elucidate the mechanism responsible for the observed variability and whether this variability may be reduced after long-term treatment as indicated by studies on the $m d x$ mouse (98).

\section{Next generation AOs}

Although extremely high-doses of PMO without modification can induce dystrophin rescue in $\mathrm{mdx}$ cardiac muscle (101), unmodified AOs are largely unsuccessful at inducing exon skipping in the heart and they do not cross the blood brain barrier $(56,58)$. This is important given that cardiac complications are observed in up to $90 \%$ of DMD patients (102) and that $1 / 3$ of DMD patients suffer cognitive impairment related to the deficiency of dystrophin in the brain (103, 104). One approach to improve $A O$ targeting to cardiac muscle is the direct conjugation of cell penetrating peptides to AOs which improves $A O$ delivery to skeletal (105-112) and cardiac $m d x$ mouse muscles (111, 113-115); however the toxicology of these conjugates has yet to be ascertained. The fact that the dystrophin protein is thought to have a long half-life should increase the possibility of achieving and maintaining therapeutically-relevant dystrophin protein levels with weekly or longer dosing intervals

\section{Regulatory hurdles}

The regulatory process for developing AOs to skip other dystrophin exons is at present cumbersome as each new $A O$ is considered a novel drug and requires the full battery of genotoxicity, rodent and non-human primate acute and chronic toxicity studies (reviewed in (116)). This stringent assessment of safety is of paramount importance, considering that there has been little experience in dosing individuals with $\mathrm{AOs}$ at high doses and for durations exceeding 1 year (and theoretically for a lifelong therapy). Nevertheless, the current studies have not reported severe drug related adverse events; in addition most of the toxicity related to AOs derives not from the individual sequences but from the chronic chemical load which is therefore largely backbone but not sequence specific. It is hoped that the positive clinical experience gained from the exon 51 skipping studies and hopefully also from other exons will allow us to gather additional information so that in the future these compounds could obtain class approval and follow a more informed and streamlined regulatory process. 
Author's Pre-print copy

Please cite as Arechavala-Gomeza et al, Current Gene Therapy 2012

\section{Conclusions}

Preclinical and clinical studies using two different chemistries have demonstrated the potential of antisense oligonucleotidemediated $D M D$ exon skipping to modify the progression of DMD. If progress in this field continues at the pace of the last decade, treatment for common DMD mutations may soon be feasible. If no sequence-specific toxic effect is found, treatment of rare mutations could follow as regulatory hurdles are overcome. Furthermore this approach could treat nonsense mutations or other frameshifting mutations located in in-frame exons that could be removed by skipping a single exon. The clinical development of next generation AOs that effectively target cardiac as well as skeletal muscle will provide a significant quality of life improvement for patients.

\section{Acknowledgements}

Virginia Arechavala-Gomeza is supported by a Health Innovation Challenge Grant from the UK Department of Health and the Wellcome Trust, Karen Anthony is supported by the Association Francaise contre les Myopathies, Jennifer Morgan is supported by a Wellcome Trust University Award and Francesco Muntoni is supported by the Great Ormond Street Hospital Children's Charity.

\section{REFERENCES}

1. Bushby K, Finkel R, Birnkrant DJ, Case LE, Clemens PR, Cripe $L$, et al. Diagnosis and management of Duchenne muscular dystrophy, part 1: diagnosis, and pharmacological and psychosocial management. Lancet Neurol. 2010;9(1):77-93. Epub 2009/12/01.

2. Simonds AK, Muntoni F, Heather S, Fielding S. Impact of nasal ventilation on survival in hypercapnic Duchenne muscular dystrophy. Thorax. 1998;53(11):949-52.

3. Eagle $M$, Baudouin SV, Chandler $C$, Giddings DR, Bullock R, Bushby K. Survival in Duchenne muscular dystrophy: improvements in life expectancy since 1967 and the impact of home nocturnal ventilation. Neuromuscul Disord. 2002;12(10):926-9.

4. Hoffman EP, Brown RH, Jr., Kunkel LM. Dystrophin: the protein product of the Duchenne muscular dystrophy locus. Cell. 1987;51(6):919-28.

5. Morris GE, Sedgwick SG, Ellis JM, Pereboev A, Chamberlain JS, Nguyen thi M. An epitope structure for the $\mathrm{C}$-terminal domain of dystrophin and utrophin. Biochemistry. 1998;37(31):11117-27.

6. Muntoni F, Torelli S, Ferlini A. Dystrophin and mutations: one gene, several proteins, multiple phenotypes. Lancet Neurol. 2003;2(12):731-40.

7. Abbs S, Tuffery-Giraud S, Bakker E, Ferlini A, Sejersen T, Mueller CR. Best practice guidelines on molecular diagnostics in Duchenne/Becker muscular dystrophies. Neuromuscul Disord. 2010;20(6):422-7. Epub 2010/05/15.

8. Ervasti JM, Campbell KP. A role for the dystrophin-glycoprotein complex as a transmembrane linker between laminin and actin. J Cell Biol. 1993;122(4):809-23. Epub 1993/08/01.

9. Ibraghimov-Beskrovnaya $O$, Ervasti JM, Leveille CJ, Slaughter CA, Sernett SW, Campbell KP. Primary structure of dystrophin-associated glycoproteins linking dystrophin to the extracellular matrix. Nature. 1992;355(6362):696702. Epub 1992/02/20.

10. Henderson DM, Lin AY, Thomas DD, Ervasti JM. The carboxy-terminal third of dystrophin enhances actin binding activity. J Mol Biol. 2012;416(3):414-24. Epub 2012/01/10.

11. Ervasti JM. Dystrophin, its interactions with other proteins, and implications for muscular dystrophy. Biochim Biophys Acta. 2007;1772(2):108-17. Epub 2006/07/11. 
12. Le Rumeur E, Winder SJ, Hubert JF. Dystrophin: more than just the sum of its parts. Biochim Biophys Acta. 2010;1804(9):1713-22. Epub 2010/05/18.

13. Ishikawa-Sakurai $\mathrm{M}$, Yoshida M, Imamura M, Davies KE, Ozawa E. ZZ domain is essentially required for the physiological binding of dystrophin and utrophin to beta-dystroglycan. Hum Mol Genet. 2004;13(7):693-702. Epub 2004/02/14.

14. Hnia K, Zouiten D, Cantel S, Chazalette D, Hugon G, Fehrentz JA, et al. ZZ domain of dystrophin and utrophin: topology and mapping of a beta-dystroglycan interaction site. The Biochemical journal. 2007;401(3):667-77. Epub 2006/10/03.

15. Crawford GE, Faulkner JA, Crosbie RH, Campbell KP, Froehner SC, Chamberlain JS. Assembly of the dystrophin-associated protein complex does not require the dystrophin $\mathrm{COOH}$ terminal domain. The Journal of cell biology. 2000;150(6):1399-410. Epub 2000/09/20.

16. Peters MF, Adams ME, Froehner SC. Differential association of syntrophin pairs with the dystrophin complex. J Cell Biol. 1997;138(1):81-93. Epub 1997/07/14.

17. Sadoulet-Puccio HM, Rajala M, Kunkel LM. Dystrobrevin and dystrophin: an interaction through coiled-coil motifs. Proceedings of the National Academy of Sciences of the United States of America. 1997;94(23):12413-8. Epub 1997/11/14.

18. Brinkmeier H. TRP channels in skeletal muscle: gene expression, function and implications for disease. Adv Exp Med Biol. 2011;704:749-58. Epub 2011/02/04.

19. Lai Y, Thomas GD, Yue Y, Yang HT, Li D, Long $C$, et al. Dystrophins carrying spectrin-like repeats 16 and 17 anchor nNOS to the sarcolemma and enhance exercise performance in a mouse model of muscular dystrophy. J Clin Invest. 2009;119(3):624-35. Epub 2009/02/21.

20. Percival JM, Anderson KN, Huang $P$, Adams ME, Froehner SC. Golgi and sarcolemmal neuronal NOS differentially regulate contractioninduced fatigue and vasoconstriction in exercising mouse skeletal muscle. J Clin Invest. 2010;120(3):816-26.

21. Cacchiarelli D, Martone J, Girardi E, Cesana M, Incitti T, Morlando M, et al. MicroRNAs Involved in Molecular Circuitries Relevant for the Duchenne Muscular Dystrophy Pathogenesis Are Controlled by the Dystrophin/nNOS Pathway. Cell Metab. 2010. Epub 2010/08/24.
22. Arechavala-Gomeza V, Kinali M, Feng L, Guglieri M, Edge G, Main M, et al. Revertant fibres and dystrophin traces in Duchenne muscular dystrophy: implication for clinical trials. Neuromuscul Disord. 2010;20(5):295-301. Epub 2010/04/17.

23. Klein CJ, Coovert DD, Bulman DE, Ray PN, Mendell JR, Burghes $\mathrm{AH}$. Somatic reversion/suppression in Duchenne muscular dystrophy (DMD): evidence supporting a framerestoring mechanism in rare dystrophin-positive fibers. Am J Hum Genet. 1992;50(5):950-9.

24. Lu QL, Morris GE, Wilton SD, Ly T, Artem'yeva OV, Strong $P$, et al. Massive idiosyncratic exon skipping corrects the nonsense mutation in dystrophic mouse muscle and produces functional revertant fibers by clonal expansion. J Cell Biol. 2000;148(5):985-96.

25. Matsumura K, Tome FM, Collin H, Leturcq F, Jeanpierre $M$, Kaplan JC, et al. Expression of dystrophin-associated proteins in dystrophinpositive muscle fibers (revertants) in Duchenne muscular dystrophy. Neuromuscul Disord. 1994;4(2):115-20.

26. Anthony K, Cirak S, Torelli S, Tasca G, Feng L, Arechavala-Gomeza V, et al. Dystrophin quantification and clinical correlations in Becker muscular dystrophy: implications for clinical trials. Brain. 2011. Epub 2011/11/22.

27. Bulfield G, Siller WG, Wight PA, Moore KJ. $\mathrm{X}$ chromosome-linked muscular dystrophy ( $\mathrm{mdx}$ ) in the mouse. Proc Natl Acad Sci $U$ S A. 1984;81(4):1189-92.

28. Hoffman EP, Morgan JE, Watkins SC, Partridge TA. Somatic reversion/suppression of the mouse $\mathrm{mdx}$ phenotype in vivo. J Neurol Sci. 1990;99(1):9-25.

29. Nicholson LV, Johnson MA, Bushby KM, Gardner-Medwin D. Functional significance of dystrophin positive fibres in Duchenne muscular dystrophy. Arch Dis Child. 1993;68(5):632-6.

30. Bushby KM, Gardner-Medwin D, Nicholson LV, Johnson MA, Haggerty ID, Cleghorn $\mathrm{NJ}$, et al. The clinical, genetic and dystrophin characteristics of Becker muscular dystrophy. II. Correlation of phenotype with genetic and protein abnormalities. J Neurol. 1993;240(2):105-12.

31. England SB, Nicholson LV, Johnson MA, Forrest SM, Love DR, Zubrzycka-Gaarn EE, et al. Very mild muscular dystrophy associated with the deletion of $46 \%$ of dystrophin. Nature. 1990;343(6254):180-2.

32. Monaco AP, Bertelson CJ, Liechti-Gallati S, Moser $H$, Kunkel LM. An explanation for the 
phenotypic differences between patients bearing partial deletions of the DMD locus. Genomics. 1988;2(1):90-5.

33. Ferreiro V, Giliberto $F$, Muniz GM, Francipane L, Marzese DM, Mampel A, et al. Asymptomatic Becker muscular dystrophy in a family with a multiexon deletion. Muscle Nerve. 2009;39(2):239-43. Epub 2008/11/18.

34. Lesca $G$, Testard $H$, Streichenberger $N$, Pelissier JF, Lestra C, Burel E, et al. [Family study allows more optimistic prognosis and genetic counselling in a child with a deletion of exons 5051 of the dystrophin gene]. Arch Pediatr. 2007;14(3):262-5. Epub 2007/01/30. Impact de l'etude familiale sur le pronostic et le conseil genetique chez un enfant porteur d'une deletion des exons 50-51 du gene de la dystrophine.

35. Melis MA, Cau M, Muntoni F, Mateddu A, Galanello R, Boccone $L$, et al. Elevation of serum creatine kinase as the only manifestation of an intragenic deletion of the dystrophin gene in three unrelated families. Eur J Paediatr Neurol. 1998;2(5):255-61.

36. Morrone A, Zammarchi E, Scacheri PC, Donati MA, Hoop RC, Servidei $S$, et al. Asymptomatic dystrophinopathy. Am J Med Genet. 1997;69(3):261-7.

37. Muntoni $F$, Di Lenarda $A$, Porcu $M$, Sinagra G, Mateddu A, Marrosu G, et al. Dystrophin gene abnormalities in two patients with idiopathic dilated cardiomyopathy. Heart. 1997;78(6):608-12.

38. Saengpattrachai $M$, Ray PN, Hawkins $C E$, Berzen A, Banwell BL. Grandpa and I have dystrophinopathy?: approach to asymptomatic hyperCKemia. Pediatr Neurol. 2006;35(2):145-9.

39. Sanchez-Arjona MB, Rodriguez-Uranga JJ, Giles-Lima M, Fernandez-Garcia R, Chinchon-Lara I, Antinolo $G$, et al. Spanish family with myalgia and cramps syndrome. J Neurol Neurosurg Psychiatry. 2005;76(2):286-9. Epub 2005/01/18.

40. Torelli S, Brown SC, Jimenez-Mallebrera C, Feng L, Muntoni F, Sewry CA. Absence of neuronal nitric oxide synthase (nNOS) as a pathological marker for the diagnosis of Becker muscular dystrophy with rod domain deletions. Neuropathol Appl Neurobiol. 2004;30(5):540-5.

41. Muntoni F, Gobbi P, Sewry C, Sherratt T, Taylor J, Sandhu SK, et al. Deletions in the 5' region of dystrophin and resulting phenotypes. J Med Genet. 1994;31(11):843-7. Epub 1994/11/01.

42. Arahata K, Beggs $\mathrm{AH}$, Honda $\mathrm{H}$, Ito $\mathrm{S}$, Ishiura S, Tsukahara T, et al. Preservation of the Cterminus of dystrophin molecule in the skeletal muscle from Becker muscular dystrophy. J Neurol Sci. 1991;101(2):148-56. Epub 1991/02/01.

43. Aartsma-Rus A, Fokkema I, Verschuuren J, Ginjaar I, van Deutekom J, van Ommen GJ, et al. Theoretic applicability of antisense-mediated exon skipping for Duchenne muscular dystrophy mutations. Hum Mutat. 2009.

44. Goemans NM, Tulinius $M$, van den Akker JT, Burm BE, Ekhart PF, Heuvelmans N, et al. Systemic Administration of PRO051 in Duchenne's Muscular Dystrophy. N Engl J Med. 2011. Epub 2011/03/25.

45. Heemskerk $H$, de Winter $C$, van Kuik $P$, Heuvelmans $N$, Sabatelli $P$, Rimessi $P$, et al. Preclinical PK and PD Studies on 2'-O-Methylphosphorothioate RNA Antisense Oligonucleotides in the mdx Mouse Model. Mol Ther. 2010. Epub 2010/04/22.

46. Cirak S, Arechavala-Gomeza V, Guglieri M, Feng L, Torelli S, Anthony K, et al. Exon skipping and dystrophin restoration in patients with Duchenne muscular dystrophy after systemic phosphorodiamidate morpholino oligomer treatment: an open-label, phase 2, dose-escalation study. Lancet. 2011;378(9791):595-605. Epub 2011/07/26.

47. Sazani P, Weller DL, Shrewsbury SB. Safety pharmacology and genotoxicity evaluation of AVI-4658. Int J Toxicol. 2010;29(2):143-56. Epub 2010/01/30.

48. Wood MJ, Gait MJ, Yin H. RNA-targeted splice-correction therapy for neuromuscular disease. Brain. 2010;133(Pt 4):957-72. Epub 2010/02/13.

49. Wilton SD, Fletcher S. RNA Splicing Manipulation: Strategies to Modify Gene Expression for a Variety of Therapeutic Outcomes. Curr Gene Ther. 2011. Epub 2011/04/02.

50. Sazani P, Graziewicz, MA and Kole, R. Antisense Drug Technology, Principles, Strategies and Applications. CBC Press. 2008:88-115.

51. Summerton JE. Morpholino, siRNA, and SDNA Compared: Impact of Structure and Mechanism of Action on Off-Target Effects and Sequence Specificity. Curr Top Med Chem. 2007;7(7):651-60.

52. Sazani P, Kole R. Therapeutic potential of antisense oligonucleotides as modulators of alternative splicing. J Clin Invest. 2003;112(4):4816.

53. Muntoni F, Bushby KD, van Ommen G. 149th ENMC International Workshop and 1st TREAT-NMD Workshop on: "planning phase i/ii clinical trials using systemically delivered antisense 
Please cite as Arechavala-Gomeza et al, Current Gene Therapy 2012

oligonucleotides in duchenne muscular dystrophy". Neuromuscul Disord. 2008;18(3):26875.

54. Amantana A, Moulton HM, Cate ML, Reddy MT, Whitehead T, Hassinger JN, et al. Pharmacokinetics, biodistribution, stability and toxicity of a cell-penetrating peptide-morpholino oligomer conjugate. Bioconjug Chem. 2007;18(4):1325-31.

55. Lu QL, Mann CJ, Lou F, Bou-Gharios G, Morris GE, Xue SA, et al. Functional amounts of dystrophin produced by skipping the mutated exon in the mdx dystrophic mouse. Nat Med. 2003;9(8):1009-14.

56. Lu QL, Rabinowitz A, Chen YC, Yokota T, Yin $\mathrm{H}$, Alter J, et al. Systemic delivery of antisense oligoribonucleotide restores dystrophin expression in body-wide skeletal muscles. Proc Natl Acad Sci U S A. 2005;102(1):198-203.

57. Gebski BL, Mann CJ, Fletcher S, Wilton SD. Morpholino antisense oligonucleotide induced dystrophin exon 23 skipping in $\mathrm{mdx}$ mouse muscle. Hum Mol Genet. 2003;12(15):1801-11.

58. Alter J, Lou F, Rabinowitz A, Yin $H$, Rosenfeld J, Wilton SD, et al. Systemic delivery of morpholino oligonucleotide restores dystrophin expression bodywide and improves dystrophic pathology. Nat Med. 2006;12(2):175-7.

59. McClorey $\mathrm{G}$, Moulton HM, Iversen PL, Fletcher S, Wilton SD. Antisense oligonucleotideinduced exon skipping restores dystrophin expression in vitro in a canine model of DMD. Gene Ther. 2006.

60. Saito T, Nakamura A, Aoki Y, Yokota T, Okada T, Osawa M, et al. Antisense PMO Found in Dystrophic Dog Model Was Effective in Cells from Exon 7-Deleted DMD Patient. PLoS ONE. 2010;5(8). Epub 2010/09/02.

61. Yokota $T$, Lu QL, Partridge $T$, Kobayashi M, Nakamura A, Takeda S, et al. Efficacy of systemic morpholino exon-skipping in duchenne dystrophy dogs. Ann Neurol. 2009.

62. van Deutekom JC, Janson AA, Ginjaar IB, Frankhuizen WS, Aartsma-Rus A, Bremmer-Bout $M$, et al. Local dystrophin restoration with antisense oligonucleotide PRO051. N Engl J Med. 2007;357(26):2677-86.

63. Kinali M, Arechavala-Gomeza V, Feng L, Cirak S, Hunt D, Adkin $C$, et al. Local restoration of dystrophin expression with the morpholino oligomer AVI-4658 in Duchenne muscular dystrophy: a single-blind, placebo-controlled, dose-escalation, proof-of-concept study. Lancet Neurol. 2009;8(10):918-28. Epub 2009/08/29.
64. Popplewell LJ, Adkin C, ArechavalaGomeza V, Aartsma-Rus A, de Winter CL, Wilton $\mathrm{SD}$, et al. Comparative analysis of antisense oligonucleotide sequences targeting exon 53 of the human DMD gene: Implications for future clinical trials. Neuromuscul Disord. 2010;20(2):10210. Epub 2010/01/19.

65. Aartsma-Rus A, De Winter CL, Janson AA, Kaman WE, Van Ommen GJ, Den Dunnen JT, et al. Functional Analysis of 114 Exon-Internal AONs for Targeted DMD Exon Skipping: Indication for Steric Hindrance of SR Protein Binding Sites. Oligonucleotides. 2005;15(4):284-197.

66. Wilton SD, Fall AM, Harding PL, McClorey G, Coleman C, Fletcher S. Antisense Oligonucleotide-induced Exon Skipping Across the Human Dystrophin Gene Transcript. Mol Ther. 2007.

67. Arechavala-Gomeza V, Graham IR, Popplewell LJ, Adams AM, Aartsma-Rus A, Kinali $M$, et al. Comparative analysis of antisense oligonucleotide sequences for targeted skipping of exon 51 during dystrophin pre-mRNA splicing in human muscle. Hum Gene Ther. 2007;18(9):798810. Epub 2007/09/05.

68. Mitrpant C, Adams AM, Meloni PL, Muntoni F, Fletcher S, Wilton SD. Rational design of antisense oligomers to induce dystrophin exon skipping. Molecular therapy : the journal of the American Society of Gene Therapy. 2009;17(8):1418-26. Epub 2009/03/19.

69. Popplewell LJ, Graham IR, Malerba A, Dickson G. Bioinformatic and Functional Optimization of Antisense Phosphorodiamidate Morpholino Oligomers (PMOs) for Therapeutic Modulation of RNA Splicing in Muscle. Methods Mol Biol. 2011;709:153-78. Epub 2011/01/05.

70. Cartegni L, Wang J, Zhu Z, Zhang MQ, Krainer AR. ESEfinder: A web resource to identify exonic splicing enhancers. Nucleic Acids Res. 2003;31(13):3568-71.

71. Fairbrother WG, Yeh RF, Sharp PA, Burge CB. Predictive identification of exonic splicing enhancers in human genes. Science. 2002;297(5583):1007-13. Epub 2002/07/13.

72. Zuker M. Mfold web server for nucleic acid folding and hybridization prediction. Nucleic Acids Res. 2003;31(13):3406-15. Epub 2003/06/26. 73. Reuter JS, Mathews DH. RNAstructure: software for RNA secondary structure prediction and analysis. BMC Bioinformatics. 2010;11:129. Epub 2010/03/17.

74. Gualandi F, Rimessi P, Trabanelli C, Spitali $P$, Neri M, Patarnello T, et al. Intronic breakpoint 
definition and transcription analysis in DMD/BMD patients with deletion/duplication at the $5^{\prime}$ mutation hot spot of the dystrophin gene. Gene. 2006;370:26-33.

75. Blau HM, Webster C, Pavlath GK. Defective myoblasts identified in Duchenne muscular dystrophy. Proc Natl Acad Sci U S A. 1983;80(15):4856-60. Epub 1983/08/01.

76. Webster C, Blau HM. Accelerated agerelated decline in replicative life-span of Duchenne muscular dystrophy myoblasts: implications for cell and gene therapy. Somat Cell Mol Genet. 1990;16(6):557-65. Epub 1990/11/01.

77. Melone MA, Peluso G, Petillo O, Galderisi $U$, Cotrufo R. Defective growth in vitro of Duchenne Muscular Dystrophy myoblasts: the molecular and biochemical basis. J Cell Biochem. 1999;76(1):118-32. Epub 1999/12/02.

78. Oexle K, Kohlschutter A. Cause of progression in Duchenne muscular dystrophy: impaired differentiation more probable than replicative aging. Neuropediatrics. 2001;32(3):1239. Epub 2001/08/25.

79. Mamchaoui K, Trollet C, Bigot A, Negroni E, Chaouch S, Wolff A, et al. Immortalized pathological human myoblasts: towards a universal tool for the study of neuromuscular disorders. Skelet Muscle. 2011;1(1):34. Epub 2011/11/02.

80. Roest PA, van der Tuijn AC, Ginjaar HB, Hoeben RC, Hoger-Vorst FB, Bakker $E$, et al. Application of in vitro Myo-differentiation of nonmuscle cells to enhance gene expression and facilitate analysis of muscle proteins. Neuromuscul Disord. 1996;6(3):195-202.

81. Goyenvalle A. Engineering U7snRNA Gene to Reframe Transcripts. Methods Mol Biol. 2012;867:259-71. Epub 2012/03/29.

82. $t$ Hoen PA, de Meijer EJ, Boer JM, Vossen RH, Turk R, Maatman RG, et al. Generation and characterization of transgenic mice with the fulllength human DMD gene. J Biol Chem. 2008;283(9):5899-907.

83. Bremmer-Bout $M$, Aartsma-Rus $A$, de Meijer EJ, Kaman WE, Janson AA, Vossen RH, et al. Targeted exon skipping in transgenic hDMD mice: A model for direct preclinical screening of humanspecific antisense oligonucleotides. Mol Ther. 2004;10(2):232-40.

84. Spitali $P$, Heemskerk $H$, Vossen RH, Ferlini $A$, den Dunnen JT, $t$ Hoen PA, et al. Accurate quantification of dystrophin mRNA and exon skipping levels in duchenne muscular dystrophy.
Lab Invest. 2010;90(9):1396-402. Epub 2010/05/12.

85. Aartsma-Rus A, Janson AA, Kaman WE, Bremmer-Bout $M$, den Dunnen JT, Baas F, et al. Therapeutic antisense-induced exon skipping in cultured muscle cells from six different DMD patients. Hum Mol Genet. 2003;12(8):907-14.

86. Bovolenta M, Scotton C, Falzarano MS, Gualandi F, Ferlini A. Rapid, comprehensive analysis of the dystrophin transcript by a custom micro-fluidic exome array. Hum Mutat. 2011. Epub 2012/01/10.

87. Arechavala-Gomeza V, Kinali $M$, Feng $L$, Brown SC, Sewry C, Morgan JE, et al. Immunohistological intensity measurements as a tool to assess sarcolemma- associated protein expression. Neuropathol Appl Neurobiol. 2010;36(4):265-74. Epub 2009/12/17.

88. Arechavala-Gomeza V, Cirak S, Anthony K, Morgan J, Muntoni F. Exon-skipping therapy for Duchenne muscular dystrophy - Authors' reply. Lancet. 2012;379(9811):e10-1. Epub 2012/01/17.

89. Kinali $M$, Arechavala-Gomeza V, Cirak S, Glover A, Guglieri M, Feng L, et al. Muscle histology vs MRI in Duchenne muscular dystrophy. Neurology. 2011;76(4):346-53. Epub 2011/01/26.

90. Cacchiarelli D, Legnini I, Martone J, Cazzella V, D'Amico A, Bertini E, et al. miRNAs as serum biomarkers for Duchenne muscular dystrophy. EMBO Mol Med. 2011. Epub 2011/03/23.

91. Cirak S, Feng L, Anthony K, ArechavalaGomeza V, Torelli S, Sewry C, et al. Restoration of the Dystrophin-associated Glycoprotein Complex After Exon Skipping Therapy in Duchenne Muscular Dystrophy. Mol Ther. 2011. Epub 2011/11/17.

92. Chen YW, Nagaraju K, Bakay M, Mclntyre $O$, Rawat $R$, Shi $R$, et al. Early onset of inflammation and later involvement of TGFbeta in Duchenne muscular dystrophy. Neurology. 2005;65(6):826-34. Epub 2005/08/12.

93. Spencer MJ, Tidball JG. Do immune cells promote the pathology of dystrophin-deficient myopathies? Neuromuscul Disord. 2001;11(67):556-64. Epub 2001/08/30.

94. Mendell JR, Campbell K, Rodino-Klapac L, Sahenk Z, Shilling C, Lewis S, et al. Dystrophin immunity in Duchenne's muscular dystrophy. N Engl J Med. 2010;363(15):1429-37. Epub 2010/10/12.

95. Yokota T, Pistilli E, Duddy W, Nagaraju K. Potential of oligonucleotide-mediated exonskipping therapy for Duchenne muscular 
dystrophy. Expert Opin Biol Ther. 2007;7(6):83142. Epub 2007/06/09.

96. Yokota T, Takeda S, Lu QL, Partridge TA, Nakamura A, Hoffman EP. A renaissance for antisense oligonucleotide drugs in neurology: exon skipping breaks new ground. Arch Neurol. 2009;66(1):32-8.

97. Beroud C, Tuffery-Giraud $S$, Matsuo $M$, Hamroun D, Humbertclaude V, Monnier N, et al. Multiexon skipping leading to an artificial DMD protein lacking amino acids from exons 45 through 55 could rescue up to $63 \%$ of patients with Duchenne muscular dystrophy. Hum Mutat. 2007;28(2):196-202.

98. Malerba A, Sharp PS, Graham IR, Arechavala-Gomeza V, Foster K, Muntoni F, et al. Chronic systemic therapy with low-dose morpholino oligomers ameliorates the pathology and normalizes locomotor behavior in $\mathrm{mdx}$ mice. Mol Ther. 2011;19(2):345-54. Epub 2010/11/26.

99. Aartsma-Rus A. Antisense-mediated modulation of splicing: Therapeutic implications for duchenne muscular dystrophy. RNA Biol. 2010;7(4). Epub 2010/06/05.

100. Heemskerk HA, de Winter $\mathrm{CL}$, de Kimpe SJ, van Kuik-Romeijn $\mathrm{P}$, Heuvelmans $\mathrm{N}$, Platenburg GJ, et al. In vivo comparison of 2'-O-methyl phosphorothioate and morpholino antisense oligonucleotides for Duchenne muscular dystrophy exon skipping. J Gene Med. 2009.

101. Wu B, Lu P, Benrashid E, Malik S, Ashar J, Doran TJ, et al. Dose-dependent restoration of dystrophin expression in cardiac muscle of dystrophic mice by systemically delivered morpholino. Gene Ther. 2009.

102. Bushby K, Muntoni F, Bourke JP. 107th ENMC international workshop: the management of cardiac involvement in muscular dystrophy and myotonic dystrophy. 7th-9th June 2002, Naarden, the Netherlands. Neuromuscul Disord. 2003;13(2):166-72.

103. Sekiguchi $M$, Zushida $K$, Yoshida $M$, Maekawa M, Kamichi S, Yoshida M, et al. A deficit of brain dystrophin impairs specific amygdala GABAergic transmission and enhances defensive behaviour in mice. Brain. 2008.

104. Ricotti V, Roberts RG, Muntoni F. Dystrophin and the brain. Dev Med Child Neurol. 2011;53(1):12. Epub 2010/12/21.

105. Fletcher S, Honeyman K, Fall AM, Harding $\mathrm{PL}$, Johnsen RD, Steinhaus JP, et al. Morpholino oligomer-mediated exon skipping averts the onset of dystrophic pathology in the $\mathrm{mdx}$ mouse. Mol Ther. 2007;15(9):1587-92.
106. Moulton HM, Fletcher S, Neuman BW, McClorey G, Stein DA, Abes S, et al. Cellpenetrating peptide-morpholino conjugates alter pre-mRNA splicing of DMD (Duchenne muscular dystrophy) and inhibit murine coronavirus replication in vivo. Biochem Soc Trans. 2007;35(Pt 4):826-8.

107. Jearawiriyapaisarn N, Moulton HM, Buckley B, Roberts J, Sazani P, Fucharoen S, et al. Sustained dystrophin expression induced by peptide-conjugated morpholino oligomers in the muscles of mdx mice. Mol Ther. 2008;16(9):16249.

108. Morcos PA, Li Y, Jiang S. VivoMorpholinos: a non-peptide transporter delivers Morpholinos into a wide array of mouse tissues. Biotechniques. 2008;45(6):613-4, 6, 8 passim.

109. Yin $H$, Moulton HM, Seow Y, Boyd C, Boutilier J, Iverson $\mathrm{P}$, et al. Cell-penetrating peptide-conjugated antisense oligonucleotides restore systemic muscle and cardiac dystrophin expression and function. Hum Mol Genet. 2008;17(24):3909-18.

110. Moulton HM, Wu B, Jearawiriyapaisarn N, Sazani P, Lu QL, Kole R. Peptide-morpholino conjugate: a promising therapeutic for Duchenne muscular dystrophy. Ann N Y Acad Sci. 2009;1175:55-60.

111. Wu B, Li Y, Morcos PA, Doran TJ, Lu P, Lu QL. Octa-guanidine morpholino restores dystrophin expression in cardiac and skeletal muscles and ameliorates pathology in dystrophic mdx mice. Mol Ther. 2009;17(5):864-71.

112. Yin H, Moulton HM, Betts C, Seow Y, Boutilier J, Iverson PL, et al. A fusion peptide directs enhanced systemic dystrophin exon skipping and functional restoration in dystrophindeficient mdx mice. Hum Mol Genet. 2009;18(22):4405-14.

113. Wu B, Moulton HM, Iversen PL, Jiang J, Li $\mathrm{J}$, Li J, et al. Effective rescue of dystrophin improves cardiac function in dystrophin-deficient mice by a modified morpholino oligomer. Proc Natl Acad Sci U S A. 2008;105(39):14814-9.

114. Jearawiriyapaisarn N, Moulton HM, Sazani $P$, Kole $R$, Willis MS. Long-Term Improvement in mdx Cardiomyopathy after Therapy with Peptideconjugated Morpholino Oligomers. Cardiovasc Res. 2009.

115. Fletcher S, Honeyman K, Fall AM, Harding $\mathrm{PL}$, Johnsen RD, Wilton SD. Dystrophin expression in the $\mathrm{mdx}$ mouse after localised and systemic administration of a morpholino antisense oligonucleotide. J Gene Med. 2006;8(2):207-16. 
Author's Pre-print copy

Please cite as Arechavala-Gomeza et al, Current Gene Therapy 2012

116. Goyenvalle A, Seto JT, Davies KE,

Chamberlain J. Therapeutic approaches to muscular dystrophy. Hum Mol Genet. 2011. Epub 2011/03/26. 
Author's Pre-print copy

Please cite as Arechavala-Gomeza et al, Current Gene Therapy 2012 